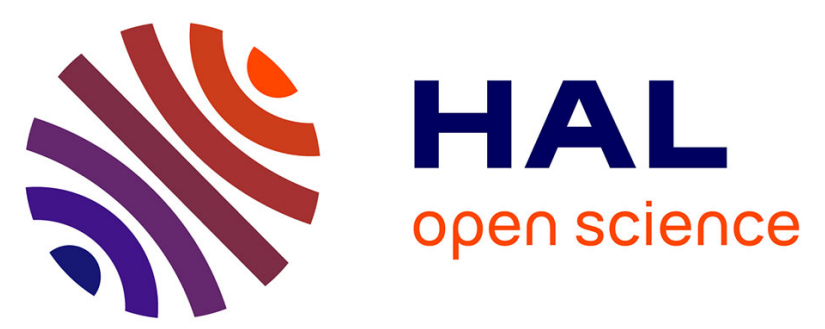

\title{
Discrepant post-filter ionized calcium concentrations by 2 common gas analyzers in continuous renal replacement therapy using regional citrate anticoagulation: another piece of the puzzle
}

R. Larcher, Nils Kuster, Anne-Sophie Bargnoux, Kada Klouche, Laurence

Pieroni, Jean-Paul Cristol

\section{To cite this version:}

R. Larcher, Nils Kuster, Anne-Sophie Bargnoux, Kada Klouche, Laurence Pieroni, et al.. Discrepant post-filter ionized calcium concentrations by 2 common gas analyzers in continuous renal replacement therapy using regional citrate anticoagulation: another piece of the puzzle. Kidney International, 2021, 99 (1), pp.268-269. 10.1016/j.kint.2020.09.021 . hal-03095402

\section{HAL Id: hal-03095402 https://hal.science/hal-03095402}

Submitted on 5 Jan 2021

HAL is a multi-disciplinary open access archive for the deposit and dissemination of scientific research documents, whether they are published or not. The documents may come from teaching and research institutions in France or abroad, or from public or private research centers.
L'archive ouverte pluridisciplinaire HAL, est destinée au dépôt et à la diffusion de documents scientifiques de niveau recherche, publiés ou non, émanant des établissements d'enseignement et de recherche français ou étrangers, des laboratoires publics ou privés. 
Romaric Larcher ${ }^{1,2}$, Nils Kuster ${ }^{1,3}$

Anne-Sophie Bargnoux ${ }^{1,3}$, Kada Klouche ${ }^{1,2}$, Laurence Pieroni $^{3}$ and Jean-Paul Cristol ${ }^{1,3}$

'PhyMedExp, University of Montpellier, INSERM (French Institut of Health and Medical Research), CNRS (French National Centre for Scientific Research), Montpellier, France; ${ }^{2}$ Intensive Care Medicine Department, Lapeyronie Hospital, Montpellier University Hospital, Montpellier, France; and ${ }^{3}$ Department of Biochemistry and Hormonology; Lapeyronie Hospital, Montpellier University Hospital, Montpellier, France

Correspondence: Romaric Larcher, Intensive Care Medicine Department, Lapeyronie Hospital, Montpellier University Hospital, 371 Avenue du Doyen G. Giraud, 34090 Montpellier Cedex 5, France. E-mail: r-larcher@chu-montpellier.fr

\section{Discrepant post-filter ionized calcium concentrations by 2 common gas analyzers in continuous renal replacement therapy using regional citrate anticoagulation: another piece of the puzzle}

To the editor: During continuous veno-venous hemodialysis with regional citrate anticoagulation, ionized calcium (iCa) measurements in pre- and post-filter samples are used to adjust calcium and citrate flows. Post-filter iCa target concentrations are within a low range $(0.25-0.34 \mathrm{mmol} / \mathrm{L})$, and blood gas analyzers (BGAs) are mainly calibrated for physiological values $(1.12-1.20 \mathrm{mmol} / \mathrm{L})$. Bias between BGAs in these low-value measurements leads to errors in adjusting the citrate dose, ${ }^{1,2}$ yet current regional citrate anticoagulation protocol is used worldwide despite the lack of standardization. ${ }^{3,4}$
Table 1 | Concordance of citrate dose adaptation induced by ionized calcium measured by ABL 90 Flex Plus (Radiometer, Copenhagen, Denmark) and GEM Premier 4000 (Werfen, Barcelona, Spain) analyzers in $\mathbf{5 0}$ post-filter samples, taken from 5 critically ill patients treated with continuous venovenous hemodialysis with regional citrate anticoagulation

\begin{tabular}{|c|c|c|c|c|}
\hline $\begin{array}{l}\text { ABL } \\
\text { GEM }\end{array}$ & $\begin{array}{l}\text { Citrate dose } \\
\text { decreased } \\
(\mathrm{Ca}<0.25)\end{array}$ & $\begin{array}{c}\text { Citrate dose } \\
\text { unchanged } \\
(\mathrm{Ca}=0.25-0.34)\end{array}$ & $\begin{array}{c}\text { Citrate dose } \\
\text { increased } \\
(\mathrm{Ca}>0.34)\end{array}$ & Total \\
\hline $\begin{array}{l}\text { Citrate dose } \\
\text { decreased } \\
(\mathrm{Ca}<0.25)\end{array}$ & 0 & 15 & 0 & 15 \\
\hline $\begin{array}{l}\text { Citrate dose } \\
\text { unchanged } \\
(\mathrm{Ca}=0.25-0.34)\end{array}$ & 0 & 9 & 26 & 35 \\
\hline $\begin{array}{l}\text { Citrate dose } \\
\text { increased } \\
(\mathrm{Ca}>0.34)\end{array}$ & 0 & 0 & 0 & 0 \\
\hline Total & 0 & 24 & 26 & 50 \\
\hline
\end{tabular}

Continuous veno-venous hemodialysis with regional citrate anticoagulation was conducted with blood flow rate at $100 \mathrm{ml} / \mathrm{min}$ and dialysate flow rate at $2000 \mathrm{ml} / \mathrm{h}$ (Multifiltrate, Fresenius Medical Care, Bad Homburg, Germany).

We analyzed 50 post-filter samples taken from 5 critically ill patients treated with continuous veno-venous hemodialysis-regional citrate anticoagulation, on GEM Premier 4000 (Werfen, Barcelona, Spain) and ABL90 Flex Plus (Radiometer, Copenhagen, Denmark) for low iCa concentrations $(0.18-0.43 \mathrm{mmol} / \mathrm{L})$. The Institutional Review Board of Montpellier University Hospital approved the study and waived the need for written consent (IRBMPT_2020_03_202000392). Consents for publication were obtained. Despite a significant linear correlation $(r=0.928)$, the ABL90 results were higher than the GEM results, with a mean difference at $0.09 \mathrm{mmol} / \mathrm{L}, 95 \%$ confidence interval (0.07-0.11; Supplementary Figures S1 and S2). These discrepancies impacted citrate dose adjustment in $82 \%$ of measurements (Table 1), inducing a poor concordance (Kappa $=0.24)$ between BGAs.

Differences were not explained by BGAs' analytical performances, as both devices appeared to be reliable and reproducible (Supplementary Table S1), but potential BGAs calibration differences could be hypothesized. Given that discrepancies were higher in post-filter samples than in $\mathrm{CaCl}_{2}$ diluted in saline (Supplementary Figure S1), a matrix effect could be involved. Our results pointed out the need for standardization of iCa monitoring to control risks of metabolic disorders (e.g., alkalosis, acidosis, hypernatremia, dyscalcemia) or filter clotting, in patients treated with continuous veno-venous hemodialysis -regional citrate anticoagulation. We, therefore, suggest calibrating BGAs using a commutable reference material close to the plasma composition (i.e., containing albumin, globulins, sodium, and other such components) but with very low iCa concentrations.

The authors acknowledge Dr. Maxence Ne for technical support. 
AUTHOR CONTRIBUTIONS

JPC conceived the study. NK, LP, and RL analyzed the data and drafted the manuscript. All authors revised the manuscript and approved the final version.

3. Kindgen-Milles D, Kram R, Kleinekofort W, Morgera S. Treatment of severe hypercalcemia using continuous renal replacement therapy with regional citrate anticoagulation. ASAIO J. 2008;54:442-444.

4. Morgera S, Schneider M, Slowinski T, et al. A safe citrate anticoagulation protocol with variable treatment efficacy and excellent control of the acid-base status. Crit Care Med. 2009;37:2018-2024.

1. Schwarzer $\mathrm{P}$, Kuhn S-O, Stracke $\mathrm{S}$, et al. Discrepant post filter ionized calcium concentrations by common blood gas analyzers in CRRT using regional citrate anticoagulation. Crit Care. 2015;19: 321.

2. D'Orazio P, Visnick H, Balasubramanian S. Accuracy of commercial blood gas analyzers for monitoring ionized calcium at low concentrations. Clinica Chimica Acta. 2016;461:34-40. 